\title{
Rootstock Effects on Fruit Quality among 'Ray Ruby' Grapefruit Trees Grown in the Indian River District of Florida
}

\author{
Greg McCollum ${ }^{1}$ and Kim D. Bowman \\ U.S. Horticultural Research Laboratory, USDA, ARS, 2001 S. Rock Road, \\ Ft. Pierce, FL 34945
}

Additional index words. citrus, total soluble solids, acidity, sheep nosing

\begin{abstract}
The objective of this experiment was to compare fruit-quality parameters of 'Ray Ruby' grapefruit grown on seven rootstocks. Four recent releases from the United States Department of Agriculture (USDA) rootstock breeding program, 'US-852', 'US897', 'US-942', and 'US-812' (all Citrus reticulata $\times$ Poncirus trifoliata hybrids), 'x639' $(C$. reticulata $\times P$. trifoliata), along with industry-standard 'Sour Orange' and 'Swingle' citrumelo were evaluated in a commercial orchard trial in Indian River County, FL. Fruit-quality data were collected in 2011-12 (eight harvests), 2012-13 (five harvests), and 2014 (single harvest). In each season, rootstock effects on fruit size, total solids, and solids acid ratio were significant. 'Sour orange' and 'Swingle' produced the largest fruit, whereas 'US-897' (a semidwarfing rootstock) produced the smallest fruit. Peel thickness (measured only in the 2011-12 season) was greatest in 'Sour Orange' early in the season, but not toward the end of the season. Misshapen ("sheep-nosed") fruit occurred more frequently on 'Sour Orange' than on other rootstocks, although the incidence of sheepnosing was minor. Analysis of variance (ANOVA) for fruit-quality data collected in January of each of the 3 years confirmed that 'Sour Orange' and 'Swingle' produced the largest fruit and 'US-897' produced the smallest fruit. Total solids were the highest in 'US-897' and the lowest in 'x639' and 'US-852'. Taken together, our data indicate that 'US-942' and 'US-897' rootstocks produced fruit with quality characteristics that equaled or exceeded 'Sour Orange' and 'Swingle', the two most common rootstocks used in the Indian River district.
\end{abstract}

The Indian River district of Florida is the world's major production region for grapefruit (Citrus paradisi Macf.), and Indian River grapefruit are valued for their high quality. In contrast to the deep, well-drained sandy soil characteristic of Florida's "central ridge," soils in the Indian River district are typically shallow, poorly drained, and referred to as "flatwoods" (Harris et al., 2010).

Grapefruit, like all commercial citrus, is produced as a composite tree consisting of a scion grafted onto a rootstock. Historically, 'Sour orange' (Citrus aurantium L.), believed to be a hybrid of Citrus maxima $\times$

Received for publication 1 Nov. 2016. Accepted for publication 5 Dec. 2016.

This research was supported in part by grants from the Florida Citrus Research and Development Foundation.

Mention of a trademark, warranty, proprietary product, or vendor does not imply an approval to the exclusion of other products or vendors that may also be suitable. The U.S. Department of Agriculture prohibits discrimination in all its programs and activities on the basis of race, color, national origin, gender, religion, age, disability, political beliefs, sexual orientation, and marital or family status. We acknowledge the technical assistance of Emily Domogtoy, James Salvatore and Wayne Brown. ${ }^{1}$ Corresponding author. E-mail: greg.mccollum@ ars.usda.gov. citrus rootstocks for grapefruit are essential if sustainable production is to be maintained (Castle et al., 2011).

Citrus rootstock breeding has been conducted by the USDA in Florida for more than a century (Soost and Rouse, 1996). The use of hybrids between Citrus spp. and Poncirus trifoliata, a member of the Rutaceae that is sexually compatible with Citrus, has been, by far, the most productive strategy for the development of new citrus rootstocks in the USDA breeding program and in other citrus rootstock breeding programs.

Between 1999 and 2010, five new citrus rootstock cultivars were released by the USDA. Four of these new rootstocks ('US-852', 'US-812', 'US-897', and 'US-942') are hybrids of Citrus reticulata (mandarin) $\times$ Poncirus trifoliata (trifoliate orange). 'US-852', released in 1999 (Bowman and Wutscher, 1999), is a hybrid of 'Changsha' mandarin $x$ 'English Large Flowered' trifoliate orange. 'US-812', released in 2001 (Bowman, 2001; Bowman and Rouse, 2006), is a hybrid of 'Sunki' mandarin and 'Benecke' trifoliate orange. Trees grown on 'US-812' rootstock are medium-sized with a wide range of scions and consistently yield large quantities of good-quality fruit. 'US-812' also exhibits resistance to citrus blight and has the CTV resistance gene $c t v R$. 'US-897' was released in 2007 (Bowman, 2007) and is a hybrid of 'Cleopatra' mandarin $\times$ 'Flying Dragon' trifoliate orange. This hybrid rootstock has field tolerance to the Phytophthora-Diaprepes disease complex, resistance to CTV, good fruit productivity, and good fruit quality (Bowman et al., 2016a). Trees produced on 'US-897' are compact, making this rootstock attractive to growers who want to increase tree density. This is especially important in Florida as tree densities are increasing from a previous average of 140 trees per acre to as many as 300 trees per acre currently. 'US-942' citrus rootstock was released in 2010 (Bowman and McCollum, 2010). Trees grown on 'US-942' are medium-sized with a wide range of scions and consistently yield large quantities of good-quality fruit (Bowman et al., 2016a). 'US-942' also exhibits field tolerance to the Phytophthora-Diaprepes disease complex, resistance to citrus blight, has the CTV resistance gene $c t v R$, and is a hybrid of 'Sunki' mandarin $\times$ 'Flying Dragon' trifoliate orange.

The 'x639' rootstock, developed in South Africa in the early 1950s, is a hybrid of 'Cleopatra' mandarin (Citrus reticulata) $\times$

Table 1. Trial planting details and proportion of trees dead in 2011 (5-6 yr age).

\begin{tabular}{lcccc}
\hline Rootstock & Planting arrangement & Number of trees planted & Number of trees died & Percent tree death \\
\hline US-897 & $6 \times 112$ & 672 & 12 & $1.8 \mathrm{~b}$ \\
US-812 & $6 \times 76$ & 456 & 12 & $2.6 \mathrm{~b}$ \\
US-852 & $6 \times 76$ & 456 & 14 & $3.1 \mathrm{~b}$ \\
Swingle & $6 \times 76$ & 456 & 16 & $3.5 \mathrm{~b}$ \\
US-942 & $6 \times 112$ & 672 & 24 & $3.6 \mathrm{~b}$ \\
x639 & $6 \times 76$ & 456 & 23 & $5.0 \mathrm{~b}$ \\
Sour orange & $6 \times 76$ & 456 & 48 & $10.5 \mathrm{a}$
\end{tabular}

Mean separations for significant analysis of variance within columns, by Duncan's multiple range test at $P<0.05$.

${ }^{\mathrm{z}}$ Planting arrangement $=$ reps $\times$ number of trees per rep.

Citrus reticulata Blanco (Grosser et al., temons, citrus scions Florida, 'Sour orange' fell out of favor sequently, 'Swingle' citrumelo ['Duncan' of the Florida central ridge, it has prov typical of the Indian River district (Baue et al., 2005; Castle et al., 2016). Improved 


\begin{tabular}{|c|c|c|c|c|c|c|c|c|}
\hline \multicolumn{9}{|c|}{ Harvest $^{z}$} \\
\hline Rootstock & 1 & 2 & 3 & 4 & 5 & 6 & 7 & 8 \\
\hline & \multicolumn{8}{|c|}{ Weight (g) } \\
\hline Sour & $326.5 \mathrm{a}^{\mathrm{y}}$ & $369.9 \mathrm{a}$ & 397.7 & 408.1 & 426.8 & 448.0 & $511.2 \mathrm{a}$ & $520.2 \mathrm{a}$ \\
\hline Swingle & $307.0 \mathrm{ab}$ & $352.4 \mathrm{ab}$ & 364.9 & 392.4 & 440.9 & 456.9 & $490.1 \mathrm{ab}$ & $492.9 \mathrm{ab}$ \\
\hline US-942 & $300.3 \mathrm{ab}$ & $330.7 \mathrm{~b}$ & 361.3 & 376.1 & 420.5 & 447.3 & $456.7 \mathrm{bc}$ & $459.7 \mathrm{bc}$ \\
\hline US-897 & $257.9 \mathrm{~b}$ & $318.6 \mathrm{~b}$ & 344.5 & 367.6 & 377 & 393.0 & $415.4 \mathrm{~d}$ & $429.0 \mathrm{c}$ \\
\hline US-812 & $292.0 \mathrm{~b}$ & $337.7 \mathrm{ab}$ & 359.8 & 385.1 & 396.2 & 441.1 & $462.2 \mathrm{bc}$ & $438.8 \mathrm{bc}$ \\
\hline US-852 & $326.2 \mathrm{a}$ & $351.9 \mathrm{ab}$ & 376.1 & 398.4 & 406.8 & 434.9 & $450 \mathrm{~cd}$ & $442.2 \mathrm{bc}$ \\
\hline x639 & $300.3 \mathrm{ab}$ & $331.3 \mathrm{~b}$ & 357.6 & 377.6 & 391.2 & 410.5 & $428.4 \mathrm{~cd}$ & $455.2 \mathrm{bc}$ \\
\hline \multirow[t]{2}{*}{$\operatorname{Pr}>\mathrm{f}$} & 0.01 & 0.1 & NS & NS & NS & NS & $<0.001$ & 0.01 \\
\hline & \multicolumn{8}{|c|}{ Height (mm) } \\
\hline Sour & $84.8 \mathrm{a}$ & $88.5 \mathrm{a}$ & $88.5 \mathrm{a}$ & 88.2 & 87.3 & 90.4 & $93.7 \mathrm{a}$ & $93.1 \mathrm{a}$ \\
\hline Swingle & $82.8 \mathrm{ab}$ & $85.9 \mathrm{ab}$ & $86 \mathrm{ab}$ & 86.2 & 88.3 & 90.3 & $92.1 \mathrm{ab}$ & $91.5 \mathrm{ab}$ \\
\hline US-942 & $90.0 \mathrm{bc}$ & $83.4 \mathrm{~b}$ & $85.5 \mathrm{ab}$ & 85.2 & 86.8 & 89.2 & $90.4 \mathrm{ab}$ & $89.2 \mathrm{abc}$ \\
\hline US-897 & $78.7 \mathrm{c}$ & $82.6 \mathrm{~b}$ & $82.2 \mathrm{c}$ & 84.4 & 84.0 & 84.3 & $86.3 \mathrm{c}$ & $86.6 \mathrm{c}$ \\
\hline US-812 & $81.3 \mathrm{abc}$ & $85.0 \mathrm{ab}$ & $84.1 \mathrm{bc}$ & 86.4 & 85.7 & 88.6 & $90.5 \mathrm{ab}$ & $87.8 \mathrm{bc}$ \\
\hline US-852 & $82.9 \mathrm{ab}$ & $85.3 \mathrm{ab}$ & $86.2 \mathrm{ab}$ & 87.3 & 86.0 & 88.3 & $89.7 \mathrm{~b}$ & $87.7 \mathrm{bc}$ \\
\hline$\times 639$ & $82.3 \mathrm{ab}$ & $84.6 \mathrm{~b}$ & $85.2 \mathrm{bc}$ & 86.6 & 86.1 & 89.8 & $89.6 \mathrm{~b}$ & $91.2 \mathrm{ab}$ \\
\hline \multirow[t]{2}{*}{$\operatorname{Pr}>\mathrm{f}$} & 0.0 & 0.03 & 0.006 & NS & NS & NS & 0.003 & 0.02 \\
\hline & \multicolumn{8}{|c|}{ Diameter $(\mathrm{mm})$} \\
\hline Sour & $92.8 \mathrm{a}$ & $97.7 \mathrm{a}$ & $99.4 \mathrm{a}$ & 100.0 & 99.1 & 100.5 & $105.3 \mathrm{a}$ & $104.9 \mathrm{a}$ \\
\hline Swingle & $89.2 \mathrm{bc}$ & $94.6 \mathrm{ab}$ & $95.0 \mathrm{bc}$ & 99.7 & 99.7 & 100.4 & $103.0 \mathrm{ab}$ & $102.6 \mathrm{ab}$ \\
\hline US-942 & $88.1 \mathrm{c}$ & $91.9 \mathrm{bc}$ & $94.5 \mathrm{bc}$ & 95.2 & 97.9 & 99.1 & $100.0 \mathrm{bc}$ & $99.9 \mathrm{bc}$ \\
\hline US-897 & $85.8 \mathrm{c}$ & $90.7 \mathrm{c}$ & $92.4 \mathrm{c}$ & 93.8 & 94 & 95 & $96.4 \mathrm{~d}$ & $96.9 \mathrm{c}$ \\
\hline US-812 & $87.8 \mathrm{c}$ & $92.7 \mathrm{bc}$ & $94.1 \mathrm{bc}$ & 95.8 & 95.4 & 98.9 & $100.3 \mathrm{bc}$ & $97.8 \mathrm{c}$ \\
\hline US-852 & $91.6 \mathrm{ab}$ & $94.5 \mathrm{ab}$ & $96.5 \mathrm{ab}$ & 97.6 & 97.5 & 99.9 & $100.9 \mathrm{bc}$ & $100.1 \mathrm{bc}$ \\
\hline x639 & $89.1 \mathrm{bc}$ & $92.6 \mathrm{bc}$ & $95.0 \mathrm{bc}$ & 96.4 & 96.1 & 97.6 & $99.0 \mathrm{~cd}$ & $100.1 \mathrm{bc}$ \\
\hline \multirow[t]{2}{*}{$\operatorname{Pr}>f$} & 0.001 & 0.005 & 0.01 & NS & NS & NS & $<0.001$ & 0.007 \\
\hline & \multicolumn{8}{|c|}{ Total soluble solids (\%) } \\
\hline Sour & $8.7 \mathrm{ab}$ & $8.6 \mathrm{~b}$ & $8.6 \mathrm{bc}$ & $8.7 \mathrm{a}$ & $9.1 \mathrm{a}$ & $9.2 \mathrm{a}$ & $9.0 \mathrm{ab}$ & $8.5 \mathrm{abc}$ \\
\hline Swingle & $8.6 \mathrm{bc}$ & $8.7 \mathrm{~b}$ & $8.7 \mathrm{bc}$ & $8.6 \mathrm{ab}$ & $9.1 \mathrm{a}$ & $9.1 \mathrm{ab}$ & $9.3 \mathrm{a}$ & $8.8 \mathrm{a}$ \\
\hline US-942 & $8.9 \mathrm{ab}$ & $8.8 \mathrm{ab}$ & $8.6 \mathrm{bc}$ & $8.7 \mathrm{a}$ & $9.3 \mathrm{a}$ & $9.5 \mathrm{a}$ & $9.1 \mathrm{ab}$ & $8.5 \mathrm{abc}$ \\
\hline US-897 & $9.1 \mathrm{a}$ & $9.1 \mathrm{a}$ & $9.1 \mathrm{a}$ & $9.0 \mathrm{a}$ & $9.2 \mathrm{a}$ & $9.4 \mathrm{a}$ & $9.3 \mathrm{a}$ & $8.9 \mathrm{a}$ \\
\hline US-812 & $8.8 \mathrm{ab}$ & $8.8 \mathrm{ab}$ & $8.8 \mathrm{ab}$ & $8.8 \mathrm{a}$ & $9.5 \mathrm{a}$ & $9.4 \mathrm{a}$ & $9.5 \mathrm{a}$ & $9.0 \mathrm{a}$ \\
\hline US-852 & $8.2 \mathrm{~cd}$ & $8.2 \mathrm{c}$ & $8.1 \mathrm{c}$ & $8.1 \mathrm{bc}$ & $8.3 \mathrm{~b}$ & $8.6 \mathrm{c}$ & $8.4 \mathrm{c}$ & $7.9 \mathrm{c}$ \\
\hline$x 639$ & $8.0 \mathrm{~d}$ & $8.1 \mathrm{c}$ & $8.1 \mathrm{c}$ & $8.0 \mathrm{c}$ & $8.3 \mathrm{~b}$ & $8.6 \mathrm{c}$ & $8.6 \mathrm{bc}$ & $8.1 \mathrm{bc}$ \\
\hline \multirow[t]{2}{*}{$\operatorname{Pr}>\mathrm{f}$} & $<0.001$ & $<0.001$ & 0.003 & 0.001 & 0.003 & 0.002 & 0.001 & $<0.001$ \\
\hline & \multicolumn{8}{|c|}{ Titratable acidity ( $\%$ citric $)$} \\
\hline Sour & $1.4 \mathrm{~b}$ & 1.25 & $1.1 \mathrm{bc}$ & $1.10 \mathrm{bc}$ & $1.07 \mathrm{ab}$ & $1.0 \mathrm{bc}$ & $0.95 \mathrm{bc}$ & 0.86 \\
\hline Swingle & $1.5 \mathrm{a}$ & 1.38 & $1.2 \mathrm{ab}$ & $1.18 \mathrm{ab}$ & $1.16 \mathrm{a}$ & $1.1 \mathrm{ab}$ & $1.02 \mathrm{ab}$ & 0.92 \\
\hline US-942 & $1.5 \mathrm{ab}$ & 1.33 & $1.2 \mathrm{~b}$ & $1.15 \mathrm{abc}$ & $1.10 \mathrm{a}$ & $1.0 \mathrm{bc}$ & $0.92 \mathrm{c}$ & 0.87 \\
\hline US-897 & $1.5 \mathrm{ab}$ & 1.37 & $1.3 \mathrm{a}$ & $1.22 \mathrm{a}$ & $1.15 \mathrm{a}$ & $1.1 \mathrm{ab}$ & $1.00 \mathrm{abc}$ & 0.90 \\
\hline US-812 & $1.5 \mathrm{ab}$ & 1.33 & $1.2 \mathrm{ab}$ & $1.13 \mathrm{abc}$ & $1.14 \mathrm{a}$ & $1.14 \mathrm{a}$ & $1.05 \mathrm{a}$ & 0.94 \\
\hline US-852 & $1.3 \mathrm{c}$ & $1.20 \mathrm{c}$ & $1.1 \mathrm{c}$ & $1.05 \mathrm{c}$ & $0.975 \mathrm{~b}$ & $1.0 \mathrm{c}$ & $0.92 \mathrm{c}$ & 0.84 \\
\hline x639 & $1.4 \mathrm{~b}$ & $1.34 \mathrm{ab}$ & $1.2 \mathrm{ab}$ & $1.16 \mathrm{ab}$ & $1.01 \mathrm{~b}$ & $1.0 \mathrm{bc}$ & $0.98 \mathrm{abc}$ & 0.89 \\
\hline \multirow[t]{2}{*}{$\operatorname{Pr}>f$} & $<0.001$ & $<0.001$ & $<0.001$ & 0.02 & 0.002 & 0.01 & 0.01 & NS \\
\hline & \multicolumn{8}{|c|}{ Total solids/titratable acidity } \\
\hline Sour & $6.2 \mathrm{a}$ & $6.9 \mathrm{a}$ & $7.6 \mathrm{a}$ & $8.0 \mathrm{a}$ & 8.6 & 8.8 & 9.5 & 9.9 \\
\hline Swingle & $5.7 \mathrm{bc}$ & $6.3 \mathrm{bc}$ & $7.2 \mathrm{ab}$ & $7.3 \mathrm{~b}$ & 7.8 & 8.2 & 9.2 & 9.7 \\
\hline US-942 & $6.2 \mathrm{a}$ & $6.7 \mathrm{ab}$ & $7.3 \mathrm{ab}$ & $7.6 \mathrm{ab}$ & 8.7 & 9.2 & 9.9 & 9.9 \\
\hline US-897 & $6.3 \mathrm{a}$ & $6.7 \mathrm{ab}$ & $7.3 \mathrm{ab}$ & $7.3 \mathrm{ab}$ & 8.0 & 8.8 & 9.3 & 9.9 \\
\hline US-812 & $6.0 \mathrm{ab}$ & $6.7 \mathrm{ab}$ & $7.3 \mathrm{ab}$ & $7.8 \mathrm{a}$ & 8.4 & 8.3 & 9.1 & 9.6 \\
\hline US-852 & $6.3 \mathrm{a}$ & $6.8 \mathrm{a}$ & $7.7 \mathrm{a}$ & $7.8 \mathrm{a}$ & 8.6 & 8.7 & 9.2 & 9.4 \\
\hline x639 & $5.6 \mathrm{c}$ & $6.1 \mathrm{c}$ & $6.8 \mathrm{~b}$ & $7.0 \mathrm{~b}$ & 8.3 & 8.4 & 8.8 & 9.1 \\
\hline$\underline{\operatorname{Pr}}>\mathrm{f}$ & 0.001 & 0.008 & 0.03 & 0.04 & NS & NS & NS & NS \\
\hline
\end{tabular}

NS $=$ nonsignificant.

Data represent means of six replicate samples of 24 fruit.

${ }^{\mathrm{z} H a r v e s t}$ dates were: 1) 11 Sept. 2011; 2) 29 Sept. 2011; 3) 20 Oct. 2011; 4) 9 Nov. 2011; 5) 8 Dec. 2011; 6) 11 Jan. 2012 ; 7 ) 29 Feb. 2012 ; and 8) 10 Apr. 2012.

${ }^{\mathrm{y}}$ Means followed by the same letter not significantly different within a column (Duncan's multiple range test).

Poncirus trifoliata. Although previously not commonly used in Florida, currently there is considerable interest in ' $x 639$ ' rootstock. In 2014, ' $\mathrm{x} 639$ ' was used for the production of 622,000 nursery trees, accounting for $14 \%$ of all nursery propagations and making it the second most widely propagated citrus rootstock in Florida (Kesinger, 2015). 'Ray
Ruby' fruit are valued for their red flesh, low seed count, and pink blush that develop in the rind. In addition to their deep red color, 'Ray Ruby' juice is sweeter than it is for comparable varieties (Saunt, 1990).

To be successful, new rootstock hybrids must produce not only good fruit yields but also fruit with acceptable quality. Accord- ing to Castle (1995) and Castle et al. (2010), yield is the major factor when selecting citrus rootstocks, although rootstock effects on fruit and juice quality can impact financial returns, particularly for fresh fruit production (Castle, 2012; Castle et al., 2010). The objective of the work reported herein was to determine the effects of 


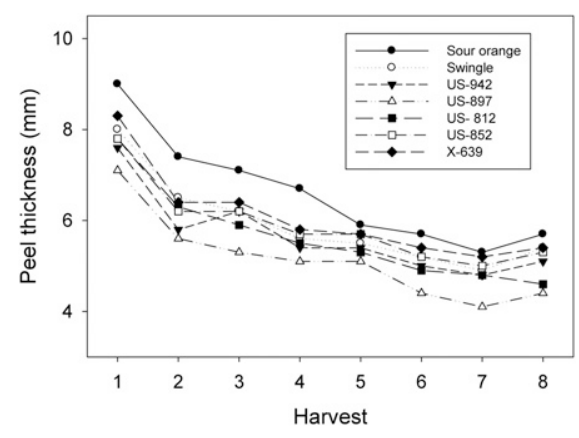

Fig. 1. Effects of rootstock on grapefruit peel thickness at eight harvest times. Each data point represents the mean of measurements taken on 72 individual fruit at each harvest. Harvest dates were: 1) 11 Sept. 2011; 2) 29 Sept. 2011; 3) 20 Oct. 2011; 4) 9 Nov. 2011; 5) 8 Dec. 2011; 6) 11 Jan. 2012; 7) 29 Feb. 2012; and 8) 10 Apr. 2012.

Table 3. Effects of rootstock on sheep-nosing of 'Ray Ruby' grapefruit.

\begin{tabular}{lc}
\hline Rootstock & Sheep-nose $^{\mathrm{z}}$ \\
\hline Sour orange & $2.3 \mathrm{a}^{\mathrm{y}}$ \\
Swingle & $2.3 \mathrm{a}$ \\
US-812 & $2.0 \mathrm{c}$ \\
US-852 & $2.1 \mathrm{bc}$ \\
US-897 & $1.98 \mathrm{c}$ \\
US-942 & $2.10 \mathrm{bc}$ \\
x639 & $2.15 \mathrm{abc}$ \\
\hline
\end{tabular}

${ }^{\mathrm{z}}$ Sheep-nosing was rated on a scale of 1-3 where $1=$ flat, 2 = round, and $3=$ sheep-nose. Each value represents the mean of six replicate samples (24 fruit per replicate) collected during eight harvests in the 2011-12 season.

${ }^{\mathrm{y}}$ Numbers not followed by the same letter differ significantly, by Duncan's multiple range test $(P<$ $0.05)$.

rootstock on fruit-quality characteristics of grapefruit in the Indian River district of Florida.

Production of all citrus types in Florida is currently being severely impacted by Huanglongbing (HLB), the most devastating of all citrus diseases. It is estimated that at least $80 \%$ of all commercial citrus trees in $100 \%$ of orchards in Florida are impacted by HLB. HLB is associated with a phloemlimited bacterium [Candidatus Liberibacter asiaticus (CLas) in Florida] that is vectored by the Asian citrus psyllid (ACP) (Diaphorina citri). It is essentially impossible to prevent the introduction of ACP, subsequent CLas infection, and eventually HLB in Florida citrus. Therefore, all orchard trials by default must now be evaluated within the context of HLB.

\section{Materials and Methods}

Four recent citrus rootstock varieties released by the USDA rootstock breeding program, 'US-852', 'US-897', 'US-942', and 'US-812', along with 'x639', 'Sour Orange', and 'Swingle', were included in the trial. Trees of 'Ray Ruby' grapefruit on the seven rootstocks were produced by a commercial citrus nursery (Phillip Rucks Citrus Nursery, Frostproof, FL) and planted into the field trial in 2005-06, on the property of a commercial citrus grower cooperator (Mr. Tom Hammond) in Indian River County, FL. Trees were planted in a site bedded as by normal commercial practice for this area, and using a randomized complete block design, with six double row beds (each bed was a replicate) for each of the seven rootstocks. Tree spacing down the row was adjusted for expected rootstock effects on tree size, with trees on the rootstocks 'Swingle', 'Sour orange', 'x639', 'US-852', and 'US-812' planted at $4.6 \mathrm{~m}$ between trees, and trees on 'US-897' and 'US-942' rootstocks planted at $3.0 \mathrm{~m}$ between trees. Total size of the experimental planting was 3624 trees, and the trial was bounded on the east and west ends by border rows of trees with the same scion. Tree survival in the trial was scored in 2011 , by counting the number of surviving trees in each bed. Fruit-quality data were collected in 2012 (eight harvests), 2013 (five harvests), and 2014 (single harvest). At each sampling time, 24 fruit were collected from 12 individual trees in a replicate. There were six replicate samples per rootstock (one from each of the six replicate beds). Individual fruit were weighed, and the diameter and height of each fruit were recorded. In the 2011-12 season, sheep nosing was rated on a scale of 1 to 3 where 1 is flat, 2 is round, and 3 is neither flat nor round, i.e., sheepnosed. Juice was extracted from the fruit using an FMC juicer. The total soluble solids (TSS) of the juice were measured with an Atago RX-5000a refractometer (Atago Co. Ltd, Bellevue, WA). Titratable acidity (TA) was determined by titration to $\mathrm{pH} 8.2$ with $0.3125 \mathrm{~N} \mathrm{NaOH}$ with a Mettler-Toledo DL50 Titrator (Mettler-Toledo, Inc., Columbus, $\mathrm{OH})$. Data for the three harvest seasons were compared for the fruit harvested in January of each year.

\section{Results}

Our objective in this study was to determine the effects of rootstock on 'Ray Ruby' grapefruit quality parameters in the Indian River citrus production area of Florida. Seven rootstocks, including four recent releases from the USDA rootstock breeding program, 'x639', and industry-standards 'Sour orange' and 'Swingle' were included in the experiment. The fruit-quality parameters were measured over three harvest seasons.

At the beginning of the experiment (trees in the field for 5-6 years), rootstock effects on tree survival were evaluated. The percentage of surviving trees in 2011 ranged from $89.5 \%$ to $98.2 \%$ (Table 1), with 'Sour orange' having significantly more tree death $(10.5 \%)$ than the other six rootstocks. In the 2011-12 season, fruit were sampled eight times from early (September) to late (May) in the season for grapefruit in Florida. At each of the eight harvests, rootstock had significant effects on some fruit-quality parameters that were measured, although not all variables were consistently different at each harvest time (Table 2).

Industry-standard rootstocks, 'Sour orange' and 'Swingle', consistently produced among the largest fruit (weight, height, and diameter), and 'US-897' produced the smallest fruit at each harvest time; however, effects of rootstock were not significant at harvests 3-6 for weight and 4-6 for height and diameter. In addition to producing the smallest fruit, 'US-897' also consistently produced fruit with the thinnest peel (Fig. 1), whereas peel thickness was the greatest in fruit produced on 'Sour orange', although differences in peel thickness were greater early in the season compared with later in the season. Misshapen ("sheep-nosed") fruit occurred more frequently on 'Sour orange' than on other rootstocks, although sheep-nosing was not a major problem with any rootstock (Table 3 ).

Total soluble solids were consistently the greatest in fruit produced on 'US-897', although not consistently greater than all others at each harvest (Table 2). In contrast, 'US-852' and ' $x 639$ ' produced fruit with consistently low soluble solids, within both statistically and not statistically significant groups. TSS increased across all rootstocks during the early part of the season reaching the highest levels at harvests 5 and 6 for each. After the sixth harvest, TSS decreased, and by April (last harvest), in some cases, TSS were as low as early in the season (September).

Although there were statistically significant differences in TA among the rootstocks, the differences were actually quite minimal: Within each harvest, the range of TA among the rootstocks rarely exceeds $0.1 \%$ (Table 2 ). Total acidity decreased consistently over the season regardless of rootstock. The ratio of TSS/TA differed significantly among the rootstocks at the first four harvests, but not at the last four. Trees on 'Sour orange' had the highest ratio at three of the eight harvests, although this was not significantly different from the ratio for trees on 'US-897', 'US-812', 'US-852', or 'US-942' at any harvests. Ratio for trees on 'Swingle' was significantly lower than trees on 'Sour orange' and 'US-852' at three of the first four harvests and significantly lower than trees on 'US-897' and 'US-942' at the first harvest. Rootstock ' $x 639$ ' produced fruit with the lowest TSS/TA ratio at every harvest.

In the 2012-13 season, fruit were sampled five times from September to May. Effects of rootstock on 'Ray Ruby' fruit quality in the 2012-13 season are shown in Table 4. As in the previous season, during the 2012-13 season, fruit produced on 'Sour orange' and 'Swingle' were the largest (weight, height, and diameter) and those on 'US-897' were the smallest. Juice TSS were the highest in fruit produced on 'US-897' rootstock and the lowest for fruit produced on ' $\mathrm{x} 639$ ' rootstock. Acidity was only significantly different among the rootstocks at the first two harvests in the 2012-13 season. In contrast to the 2011-12 season, TA was fairly consistent 


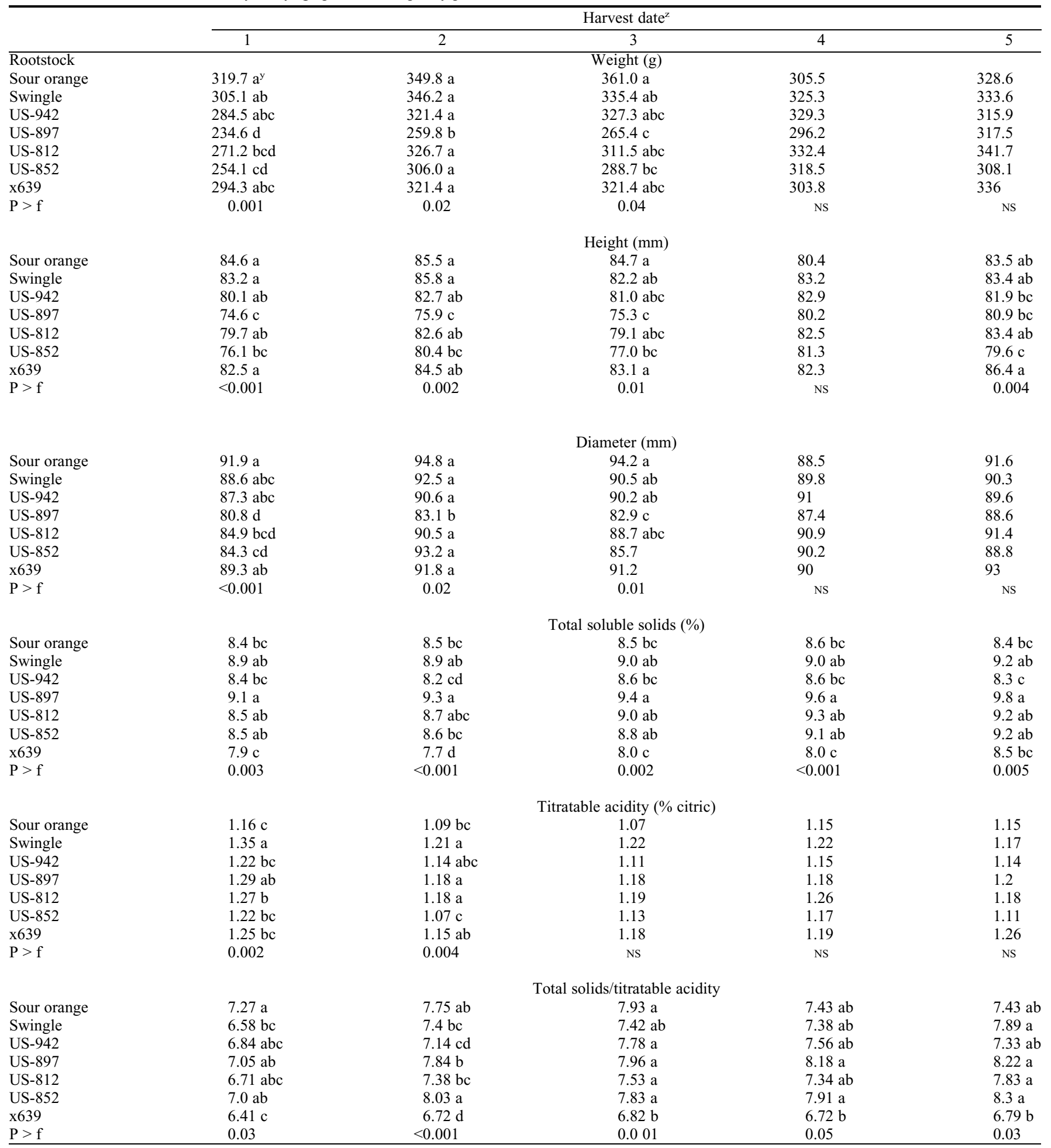

NS = nonsignificant.

Data represent means of six replicate samples of 24 fruit.

${ }^{\mathrm{z}}$ Harvest dates were: 1) 2 Oct. 2012; 2) 6 Nov. 2012; 3) 27 Nov. 2012; 4) 18 Dec. 2012; and 5) 16 Jan. 2012.

${ }^{y}$ Means followed by the same letter within a column are not significantly different (Duncan's multiple range test).

over the course of the five harvests. There were no significant differences in the TSS: TA ratios during the $2012-13$ season, although ratios were numerically highest for fruit produced on 'US-897' rootstock.

In the 2013-14 season, fruit were only harvested once in January to allow for com- parisons at a single harvest over 3 years. Analysis of variance for fruit-quality data collected in January of each of the 3 years (Table 5) confirmed that 'Sour orange' and 'Swingle' consistently produced the largest fruit, and 'US-897' produced the smallest fruit. Total solids were significantly higher on
'US-897' than all other rootstocks and significantly lower on ' $x 639$ ' than all other rootstocks. Total solids for trees on 'Sour orange' were intermediate in value and not significantly different from trees on 'US-942' or 'US-852'. Total solids:acid ratio was significantly higher on 'US-812', 'US-852', 
Table 5. Effects of rootstock on 'Ray Ruby' grapefruit fruit size parameters over three harvest seasons (2011-14). In each year, fruit were harvested in January.

\begin{tabular}{llccccc}
\hline & \multicolumn{5}{c}{ Fruit-quality parameter } \\
\cline { 2 - 6 } Rootstock & Wt $(\mathrm{g})$ & Ht $(\mathrm{mm})$ & Diam $(\mathrm{mm})$ & TSS $(\%)$ & Acid (\% citric) & TSS/acid \\
\hline Sour & $382.8 \mathrm{a}$ & $86.9 \mathrm{a}$ & $96.5 \mathrm{a}$ & $8.6 \mathrm{~cd}$ & $1.11 \mathrm{~d}$ & $7.87 \mathrm{ab}$ \\
Swingle & $374.6 \mathrm{ab}$ & $86.0 \mathrm{a}$ & $94.4 \mathrm{a}$ & $8.9 \mathrm{~b}$ & $1.20 \mathrm{a}$ & $7.54 \mathrm{~b}$ \\
US-812 & $361.3 \mathrm{~b}$ & $84.3 \mathrm{~b}$ & $93.0 \mathrm{~b}$ & $9.0 \mathrm{~b}$ & $1.12 \mathrm{~b}$ & $7.95 \mathrm{a}$ \\
US-852 & $358.4 \mathrm{~b}$ & $83.6 \mathrm{~b}$ & $93.8 \mathrm{~b}$ & $8.5 \mathrm{~d}$ & $1.08 \mathrm{~d}$ & $7.97 \mathrm{a}$ \\
US-897 & $328.7 \mathrm{c}$ & $81.1 \mathrm{c}$ & $89.6 \mathrm{c}$ & $9.2 \mathrm{a}$ & $1.18 \mathrm{ab}$ & $7.95 \mathrm{a}$ \\
US-942 & $362.8 \mathrm{~b}$ & $84.5 \mathrm{~b}$ & $93.4 \mathrm{~b}$ & $8.7 \mathrm{c}$ & $1.12 \mathrm{~cd}$ & $7.92 \mathrm{a}$ \\
x639 & $358.0 \mathrm{~b}$ & $87.0 \mathrm{a}$ & $94.1 \mathrm{~b}$ & $8.1 \mathrm{e}$ & $1.08 \mathrm{~d}$ & $7.19 \mathrm{c}$ \\
\hline
\end{tabular}

TSS $=$ total soluble solids.

Each value represents the mean of six replicate samples ( 24 fruit per sample). Those values within the same columns and not followed by the same letter were significantly different by Duncan' multiple range test $(P<0.05)$. Fruit were harvested in January of 2012, 2013, and 2015.

'US-897', and 'US-942' rootstocks than on 'Swingle', and the ratio was significantly lower on ' $\mathrm{x} 639$ ' than all other rootstocks. Total acid was significantly higher in juice produced on 'Swingle' rootstock than all others and the lowest in 'US-852'.

\section{Discussion}

Our results indicate that 'Ray Ruby' grapefruit produced on the new USDA trifoliate hybrid rootstocks for the most part produced fruit with quality equivalent to 'Sour orange', and 'Swingle', two traditional rootstocks used in the Indian River district.

This orchard trial was conducted in an area where HLB, a disease that has crippled the Florida citrus industry during the last decade, is rampant, and during the course of this experiment, the trees showed increasingly severe symptoms. By the 3 rd year of the experiment, essentially $100 \%$ of the trees were showing HLB symptoms. Previous reports have indicated some improved tree survival and yield on the rootstocks 'US897' and 'US-942' after trees become infected with CLas, causal agent of HLB (Albrecht and Bowman, 2011; Bowman et al., 2016a, 2016b). Tree survival in the trial of the four U.S. rootstocks was superior to 'Sour orange' at the beginning of our study of fruit-quality effects. Although data were not available regarding tree survival or health at later times during this study, anecdotal observations of the orchard both by citrus scientists and industry personnel support the slower rate of decline in trees on 'US-897' and 'US-942' rootstocks as compared with the other rootstocks in the trial.

Fruit produced on trees affected by HLB have lower soluble solids than do fruit produced on healthy trees (Baldwin et al., 2010; Bassanezi et al., 2009). The consistently low soluble solid content of fruit produced on ' $\mathrm{x} 639$ ' suggests that rootstock may be a poor choice for grapefruit production in the Indian River district where HLB is endemic. On the other hand, fruit produced on 'US-897' rootstock had consistently high soluble solids, thin peel, and the least amount of sheep-nosing, all desirable quality attributes for grapefruit. The reduced sheep-nosing of fruit produced on
'US-897' rootstock may be related to the thin rind of fruit, as sheep-nosing has been associated with thick peels (Wutscher, 1976). Syvertson et al. (2005) found that less sheep-nosing was observed on trees with small fruit. The smaller size of 'US897' fruit may have contributed to the least amount of sheep-nosing. Although fruit produced on 'US-897' were the smallest of all rootstocks, the positive attributes suggest that 'US-897' may be a good choice for grapefruit production in the Indian River district. In addition to the positive impact of 'US-897' on 'Ray Ruby' fruit quality observed in this experiment, because 'US-897' produces compact trees, it allows for greater tree densities than standard rootstock varieties and potentially higher productivity per area (Bowman et al., 2016a).

Because of scheduling problems inherent when conducting orchard trials with grower cooperators, it was not possible to collect yield data during the experiment. Grapefruit are typically "spot-picked," especially early in the season. Spot-picking was not uniform throughout the trial and occurred without notification. Although the yield of marketable fruit is a critically important characteristic when selecting rootstocks for a particular area, effects on fruit quality are also of great importance. Our data demonstrate clearly the impacts of these rootstocks on fruit quality and suggest that 'US-942' and 'US-897' rootstocks are promising rootstocks for the production of grapefruit in the Indian River district. It remains to be seen if the most promising rootstocks in this orchard trial will continue to perform better than others when infected by CLas.

\section{Literature Cited}

Albrecht, U. and K.D. Bowman. 2011. Tolerance of the trifoliate citrus hybrid US-897 (Citrus reticulata Blanco x Poncirus trifoliata $\mathrm{L}$. Raf.) to Huanglongbing. HortScience 46:1622.

Albrecht, U., G. McCollum, and K.D. Bowman. 2012. Influence of rootstock variety on Huanglongbing disease development in field-grown sweet orange (Citrus sinensis [L.] Osbeck) trees. Sci. Hort. 138:210-220.

Baldwin, E., A. Plotto, J. Manthey, G. McCollum, J. Bai, M. Irey, R. Cameron, and G. Luzio. 2010.
Effect of Liberibacter infection (Huanglongbing disease) of citrus on orange fruit physiology and fruit/fruit juice quality: Chemical and physical analyses. J. Agr. Food Chem. 58:1247-1262.

Bassanezi, R.B., L.H. Montesino, and E.S. Stuchi. 2009. Effects of huanglongbing on fruit quality of sweet orange cultivars in Brazil. Eur. J. Plant Pathol. 125:565-572.

Bauer, M., W. Castle, B. Boman, and T. Obreza. 2005. Economic longevity of citrus trees on Swingle citrumelo rootstock and their suitability for soils in the Indian River region. Proc. Annu. Meet. Fla. State Hort. Soc. 118:24-27.

Bowman, K.D. 2001. Notice to fruit growers and nurserymen relative to the naming and release of the US-812 citrus rootstock. U.S. Dept. Agr., ARS, Washington, D.C.

Bowman, K.D. 2007. Notice to fruit growers and nurserymen relative to the naming and release of the US-897 citrus rootstock. U.S. Dept. Agr., ARS, Washington, D.C.

Bowman, K.D. and G. McCollum. 2010. Notice to fruit growers and nurserymen relative to the naming and release of the US-942 citrus rootstock. U.S. Dept. Agr., ARS, Washington, D.C.

Bowman, K.D. and G. McCollum. 2015. Five new citrus rootstocks with improved tolerance to huanglongbing. HortScience 50:17311734.

Bowman, K.D. and R.E. Rouse. 2006. US-812 citrus rootstock. HortScience 41:832-836.

Bowman, K.D. and H.K. Wutscher. 1999. Notice to fruit growers and nurserymen relative to the naming and release of the US-852 citrus rootstock. U.S. Dept. Agr., ARS, Washington, D.C

Bowman, K.D., L. Faulkner, and M. Kesinger. 2016a. New citrus rootstocks released by USDA 2001-2010: Field performance and nursery characteristics. HortScience 51:12081214.

Bowman, K., G. McCollum, and U. Albrecht 2016b. Performance of 'Valencia' orange (Citrus sinensis [L.] Osbeck) on 17 rootstocks in a trial severely affected by Huanglongbing disease. Sci. Hort. 201:355-361.

Castle, W. 1995. Rootstock as a fruit quality factor in citrus and deciduous tree crops. N.Z. J. Crop Hort. Sci. 23:383-394.

Castle, W.S. 2012. Horticultural and economic impact of rootstocks on fresh-market 'Marsh' grapefruit. HortScience 47:1007-1013.

Castle, W.S., J.C. Baldwin, R.P. Muraro, and R. Littell. 2010. Performance of 'Valencia' sweet orange trees on 12 rootstocks at two locations and an economic interpretation as a basis for rootstock selection. HortScience 45:523-533.

Castle, W.S., K.D. Bowman, J.C. Baldwin, J.W. Grosser, and F.G. Gmitter, Jr. 2011. Rootstocks affect tree growth, yield, and juice quality of 'Marsh' grapefruit. HortScience 46:841-848.

Castle, W.S., K.D. Bowman, J.W. Grosser, S.H. Futch, and J.H. Graham. 2016. Florida Citrus Rootstock Selection Guide. 3rd ed. <https:// edis.ifas.ufl.edu/pdffiles/HS/HS126000.pdf>.

Grosser, J.W., V. Medina-Urrutia, G. Ananthakrishnan, and P. Serrano. 2004. Building a replacement sour orange rootstock: Somatic hybridization of selected mandarin + pummelo combinations. J. Amer. Soc. Hort. Sci. 129:530 534.

Harris, W.G., M. Chrysostome, T.A. Obreza, and V.D. Niar. 2010. Soil properties pertinent to 
horticulture in Florida. HortTechnology 20:1018.

Kesinger, M. 2015. 2015 Citrus Budwood Ann. Rpt. 2014-2015. Bureau of Citrus Budwood Registration, FL Dept. of Agriculture and Consumer Services, Winter Haven, FL.

Saunt, J. Citrus varieties of the world. 1990. Sinclair Int. Ltd, Norwich.
Soost, R.K. and M.L. Roose. 1996. Citrus, p. 257 323. In: J. Janick and J.N. Moore (eds.). Fruit breeding, Vol. I: Tree and tropical fruits. Wiley, Hoboken, NJ.

Stover, E. and W. Castle. 2002. Citrus rootstock usage, characteristics and selection in the Florida Indian River region. HortTechnology 12:143147.
Syvertson, J., G. Albrigo, J. Dunlop, and M. Ritenour. 2005. Growth conditions, crop load and fruit size affect sheepnosing in grapefruit Proc. Annu. Meet. Fla. State Hort. Soc. 118:2834.

Wutscher, H. 1976. Influence of night temperatures and day length on fruit shape of grapefruit. J. Amer. Soc. Hort. Sci. 101:573-575. 